http://dx.doi.org/10.12775/szhf.2017.043

PAWEe URBAŃSKI

Uniwersytet im. Adama Mickiewicza, Poznań, Polska

e-mail: paziu1984@wp.pl

\title{
W obronie rozumu nie do końca oświeconego, czyli kilka uwag o refleksyjności i krytyce
}

Jednostka jest dzieckiem swojego świata. Może się nadymać, jak chce, lecz poza ten świat nie wyjdzie'.

„Krytyka Oświecenia” stała się dziś frazesem powielanym po stokroć $\mathrm{w}$ różnych formach oraz z różnych pozycji. Krytyczny stosunek do Oświecenia można uznać jednak za co najmniej dziwny. Istnieje przecież powszechny konsensus co do tego, że złożoność współczesnego świata społecznego wskazuje na to, iż rozum nie znajduje się już w jego centrum jako jego najwyższa zasada organizująca. Dlaczego więc zamiast budowania nowych propozycji teoretycznych badacze odczuwają nieustanną potrzebę krytyki rozumu? Odpowiedź na to pytanie może brzmieć następująco - rzeczywistość wyprzedziła myślenie, $\mathrm{z}$ kolei samo myślenie nie znalazło jeszcze sposobu, aby tę złożoną rzeczywistość uchwycić za pomocą innych kategorii niż te, które proponowało Oświecenie. Dla Oświecenia myślenie o tym, co społeczne, dotyczy raczej syntetycznej jedności niż nieredukowalnego bogactwa złożoności, przed którą syntetyczne zdolności rozumu dziś kapitulują. Stąd być może nieustanna "praca żałoby”, jaką uprawiają intelektualiści zarówno z prawa,

\footnotetext{
${ }^{1}$ G. W. F. Hegel, Wykłady z historii filozofii, przeł. Ś. F. Nowicki, t. I, Warszawa 1994, s. 78.
} 
jak i z lewa. Jednakże w tym sensie krytyka nie dotyczyłaby bezpośrednio Oświecenia, lecz świata naukowego, który utracił kontrolę nad przedmiotem swoich badań.

Celem niniejszego tekstu jest przedstawienie procesów autonomizacji rozumu oraz ich wpływ na kształtowanie się nauk społecznych. Stawiam tezę, że od czasów Oświecenia coraz bardziej pogłębia się przepaść pomiędzy postępującą dynamiką złożoności świata społecznego a naukowymi sposobami jego konceptualizacji. Wychodzę od opisanego przez Michela Foucaulta przykładu cyklicznych niedoborów żywności, jakie trapią Francję przez cały XVIII wiek. Pokażę, w jaki sposób administracja państwowa opanowuje ten problem w sposób praktyczny, posługując się między innymi techniką inżynieryjną oraz naukami ekonomicznymi, prowokując przez to $\mathrm{z}$ jednej strony coraz większą współzależność pomiędzy grupami społecznymi, z drugiej zaś stwarzając zupełnie nowe warunki do samorozumienia tego, co społeczne. Przez pryzmat tego konkretnego przykładu, stopniowo uogólniając swoją argumentację, będę pytał o praktyczne sposoby kształtowania się nauk społecznych w kontekście społecznie konstruowanego rozumu.

\section{O nieudanej konieczności i złożoności świata społecznego}

„Refleksja filozoficzna nie ma nic innego na celu jak tylko usunięcie momentów przypadkowych" - powiada Hegel. Odo Marquard, przytaczając tę myśl Hegla, proponuje niezwykle interesujący sposób rozumienia tego, co przypadkowe. Stwierdza on, że przypadek jest być może nieudaną koniecznością $\mathrm{w}$ takim sensie, $\mathrm{w}$ jakim można postawić pytanie o to, co niezdeterminowane - w ostatniej instancji ${ }^{2}$. Tak rozumiana konieczność w odniesieniu do świata społecznego wymagałaby raczej serii powtórzeń, procesów odnawiania czy nieustannego wykonywania tych samych działań niż koncepcji pierwszej przyczyny, causa sui. Pojawienie się konieczności polegałoby zatem na praktycznym stabilizowaniu zdarzeń określanych jako przypadkowe i nieprzewidywalne. Mówiąc wprost, coś, co się przydarza jako konieczność, należy dopiero zrobić. Reinhart Koselleck zauważa, że wraz z państwową instytucjonalizacją przypadku zmianie ulega również ludzki stosunek do świata: „doświadczenie, które było dla nas wskutek zaskoczenia jednorazowe, prze-

${ }^{2}$ Patrz: O. Marquard, Apologia przypadkowości, przeł. K. Krzemieniowa, Warszawa 1994. 
mienia się w rosnącą wiedzę o możliwościach takich jednorazowych zaskoczeń [...]. Wszystko, co można powiedzieć o doświadczeniu powtarzalności i radzeniu sobie z jednorazowością, odnosi się zatem zawsze do żyjących razem pokoleń, których wzajemna komunikacja pozostaje zrozumiała”3. Weźmy na przykład nauki matematyczne, rachunek prawdopodobieństwa oraz statystykę, które w drugiej połowie XVIII wieku pozwalały na sprawne wkalkulowanie przypadku w obszar świata społecznego, umożliwiając władzy państwowej podejmowanie praktycznych działań, które oswajały tzw. zdarzenia rzadkie, występujące w sposób nieregularny i niedające się w żaden sposób przewidzieć tylko na podstawie bezpośredniego poznania. Zdarzenia rzadkie i nieprzewidywalne, dzięki matematyce oraz innym systemom wiedzy naukowej, stanowiły pole racjonalnych działań dla kontrolowania wielu dziedzin aktywności społecznej oraz nie-ludzkiej przyrody ${ }^{4}$. Epidemie, niedobory żywności, klęski urodzaju, klęski żywiołowe, katastrofy handlowe ${ }^{5}$, migracje ludności, głód - oto podstawowy zestaw fenomenów, którymi w XVIII wieku aparat władzy może sterować, czyniąc z przypadku „zdarzenie” podlegające określonym zabiegom ontologicznego stabilizowania ${ }^{6}$.

${ }^{3}$ R. Koselleck, Warstwy czasu, przeł. K. Krzemieniowa, J. Merecki, [w:] tenże, Warstwy czasu - studia z metahistorii, Warszawa 2012, s. 17.

${ }^{4}$ Patrz: A. Desrosieres, Politics of large numbers, trans. C. Naish, Harvard University Press, London 1998.

${ }^{5}$ Peter Sloterdijk, odnosząc się do pojawiającej się w XVIII wieku instytucji ubezpieczeń, zauważa, że: „W istotnych punktach asekuracja zawodów handlowych zajmuje miejsce tego, co dotąd zdawało się być wyłącznie w rękach Boga. Dotyczy to zwłaszcza zabezpieczenia przed skutkami nieprzewidywalnych zdarzeń losowych. Modlitwa jest dobra, ubezpieczenie lepsze" (P. Sloterdijk, Kryształowy pałac, przeł. B. Cymbrowski, Warszawa 2011, s. 109). Los nie znajduje się już w rękach siły wyższej, a rzeczywistość, w której można się ubezpieczyć od tego, co nieprzewidywalne, wydaje się bardziej stabilna - przynajmniej w tym obszarze życia społecznego, który wcześniej zdany był jedynie na przypadek. Powszechność instytucji ubezpieczeniowych umożliwiła ujarzmienie przypadku jako czegoś, co można opanować na poziomie społecznym.

${ }^{6}$ Taka działalność wymaga precyzyjnie określonej wiedzy, pozyskiwania informacji oraz sposobów jej porządkowania. W tym kontekście można przytoczyć przykład Condorceta i jego propozycji „spisów powszechnych”, z których władza królewska korzystała. Condorcet pisze tak: „Aby napisać historię jednostek, wystarczy zebrać fakty; natomiast historia mas może oprzeć się jedynie na obserwacjach, ażeby zaś dokonać ich właściwego wyboru, aby uchwycić cechy istotne, do tego trzeba już wiedzy, do tego zaś, by obserwacje odpowiednio wyzyskać, niemal tyle samo filozofii. Przedmiotem tych obserwacji są zresztą rzeczy zwyczajne, rzucające się w oczy, które każdy, jeżeli zechce, może dostrzec." (A. N. Condorcet, Szkice obrazu postępu ducha ludzkiego przez dzieje, przeł. B. Suchodolski, Warszawa 1957, s. 208). George Sorel sugeruje nawet, że Condorcet wymyślił w ten sposób system ankietowy. Innym ciekawym przy- 
Proponuję przez chwilę skupić się na zjawisku niedoboru żywności, dobrze opisanym przez Michela Foucaulta, by określić sposób wytwarzania konieczności w wymiarze praktycznym, a tym samym uchwycić proces konstytuowania się pojęcia konieczności jako porządku społecznego.

Jak jednak konkretnie i na poziomie instytucjonalnym, na poziomie określonych technik rządzenia i zarządzania polityczno-ekonomicznego, walczy się z owymi niedoborami w społeczeństwie takim, jak społeczeństwo francuskie XVII-XVIII wieku. Otóż funkcjonuje tu, i to już od dawna, cały system o charakterze, powiedziałbym, jednocześnie prawnym i dyscyplinarnym, system przepisów i zarządzeń mających zasadniczo na celu zapobieganie niedoborom żywności [...], ograniczenie wzrostu cen, prawo do składowania żywności, aż do jego zakazu, co wiąże się z koniecznością natychmiastowej sprzedaży oraz ograniczenia eksportu, zakaz wysyłania zboża za granicę7.

Chłopi, nie notując wystarczających zysków, nawet w latach, gdy zbiory są obfite - będą się z konieczności skłaniać ku mniej intensywnym zasiewom. Im mniejszy zysk, tym mniej będą w stanie obsiewać - to jasne. Bezpośrednim zaś skutkiem tej sytuacji będzie zależność od najlżejszych anomalii pogodowych, najłagodniejszych oscylacji. Najmniejszy przymrozek, byle susze czy wilgotność i ilość zboża spada poniżej poziomu wystarczającego do wyżywienia populacji, w następnym roku pojawia się niedobór. Tak oto owa polityka [...] grozi niedoborem i buntem, którym miała właśnie przeciwdziałać ${ }^{8}$.

Niedobór w skali globalnej znika pod warunkiem, że dla pewnej liczby ludzi i na określonych rynkach zaczyna się pewna rzadkość, pewien wzrost cen, że pojawiają się trudności z kupnem zboża, a zatem także głód, w wyniku czego pewna liczba ludzi może umrzeć. Właśnie pozwalając owym ludziom umrzeć z głodu, czyni się z niedoboru chimerę i zapobiega się temu, by przybrała po-

kładem „spisów powszechnych” była postać Vicqu d’Azur, królewskiego urzędnika do spraw zdrowia. Proponował on, aby stworzyć medyczną mapę Francji, która miałaby przedstawiać charakterystyczne dla danego regionu schorzenia. Wraz z tym pomysłem pojawia się również potrzeba sporządzania spisów dotyczących urodzeń, zgonów, małżeństw czy przestępstw. W ten sposób nieokreślona masa ludzi oraz zachowań przekształca się w dobrze kontrolowany zasób zwany populacją.

${ }^{7}$ M. Foucault, Bezpieczeństwo, terytorium i populacja, przeł. M. Herrer, Warszawa 2010, s. 52 .

${ }^{8}$ Tamże, s. 54. 
stać nowej plagi, tak jak to się dzieje w przypadku poprzednich systemów. Zdarzenie niedoboru zostaje w ten sposób rozmyte. Plaga niedoboru znika, rzadkość jednak, która sprawia, że ludzie umierają z głodu, nie tylko nie znika, lecz nawet nie może zniknąć.

Nadwyżka, jak i niedobór żywności, które były czymś przypadkowym u progu XVIII wieku, nagle stały się przedmiotem racjonalnych działań nastawionych głównie na osiąganie zysków. Mniej więcej w tym samym czasie „Akademia nauk nagradza Dransy’ego za jego pracę o młynach, a inżynier ten buduje fabryki w Corbeil, w których zaprowadzono nowy sposób mielenia, tzw. ekonomiczny" ${ }^{10}$. Dzięki technice inżynieryjnej praca młynów zaczyna sprzyjać akumulacji, ta $\mathrm{z}$ kolei pozwala w większym stopniu zabezpieczyć się przed nieoczekiwanym wystąpieniem niedoborów żywności na rynku. Nadwyżka i niedobór nie znikają zatem, zmienia się natomiast ich status ontologiczny. To znaczy z tego, co nieprzewidywalne stały się przedmiotem poznania i racjonalnej manipulacji. Wydaje się zatem, że problemem nie jest całkowite zapobieganie „zdarzeniom rzadkim”, co właściwie skoordynowany system regulacji dotyczący dystrybucji oraz cyrkulacji skutków z nimi związanych. Foucault twierdzi nawet, że nie chodzi tu o pełne wykluczenie przypadku, lecz o to, by nim grać w taki sposób, aby sam siebie neutralizował. Administracyjna prewencja nie likwiduje więc ryzyka związanego z nieprzewidywalnością „natury” (np. niedających się przewidzieć klęsk urodzajów prowadzących wprost do zjawiska głodu), lecz przezornie się zabezpiecza i ogranicza skutki, a w momencie ich wystąpienia nierówno rozdysponowuje je pomiędzy poszczególne grupy społeczne.

Władza rozdziela to, co przypadkowe w taki sposób, aby zapobiegać negatywnym zdarzeniom w sferze politycznej i społecznej, takim jak bunt, niestabilność rynków czy rewolucja, co rzecz jasna nie zawsze się udaje. Nie udaje się, dlatego że wzrastający poziom kontroli sił poza ludzkich staje się odwrotnie proporcjonalny do kontroli życia społecznego, które właśnie w wyniku politycznego stabilizowania natury powoduje, iż działalność wielu grup społecznych staje się coraz bardziej współzależna w swym dążeniu do bezpieczeństwa i zaspokajania własnych potrzeb. Zasięg i skala tej współzależności dotyczy ludzi, którzy nie znają się osobiście, nie tworzą lokalnej wspólnoty interesów i nie troszczą się o siebie nawzajem. W tym sensie po-

\footnotetext{
9 Tamże, s. 64.

${ }^{10}$ G. Sorel, Złudzenia postępu, przeł. E. Breiter, Kraków 2015, s. 104-105.
} 
szczególne działania ludzkie stają się coraz bardziej działaniami społecznymi, czymś wielokrotnie złożonym, co wykracza poza horyzont bezpośredniego doświadczenia rzeczywistości, w której się żyje.

Proces politycznego stabilizowania natury jest zatem niezwykle kruchy i niejednoznaczny w swych konsekwencjach. Z jednej strony skutecznie oswaja przypadek, wprowadzając szereg regularności instytucjonalnych, z drugiej zaś skutkuje pojawieniem się problemów w obszarze społecznym, które z kolei zwrotnie mogą ją destabilizować. Polityczna stabilizacja natury redukuje wystąpienie buntu, lecz go absolutnie nie wyklucza, poddaje głód cyrkulacji, lecz go nie likwiduje. Również ryzyko związane z występowaniem epidemii czy niestabilnością rynków podlega tej logice. To, co przypadkowe, staje się więc konieczne o tyle tylko, o ile sama konieczność funkcjonuje w sposób wadliwy, jest zwyczajnie nieudana - jak mówi Marquard. Nieudana konieczność raczej krąży po obszarach życia codziennego, niż powszechnie obowiązuje. Tym samym ustanawia enklawy bezpiecznych regularności, choć jednocześnie pozwala na rozpraszanie przypadku, w taki sposób, że z perspektywy instytucji oraz procesów zarządzania staje się on bez znaczenia. Stąd też dla niektórych grup społecznych to, co nazywa się naturą, pomimo swojej kapryśności, może wydawać się bardziej przewidywalne niż polityka; dla niektórych zaś wręcz odwrotnie. Na przykład chłopstwo i zubożała klasa rzemieślnicza pod wpływem wzrastającej współzależności z innymi grupami społecznymi stają się o wiele bardziej podatne na wahania pogody oraz abstrakcyjnej siły rynków niż wcześniej. Z kolei zamożne warstwy mieszczaństwa mogą w tym samym okresie bogacić się dzięki spekulacjom i wyprzedaży po zawyżonych cenach zgromadzonych zawczasu zasobów.

Można zatem powiedzieć, że tak zorganizowany świat społeczny jest jeden, lecz sposób, w jaki poszczególne grupy go zamieszkują, sprawia, że ową jedność można pojmować równie dobrze jako nieredukowalną do jedności wielość, gdzie każdemu stanowi natury odpowiada określony stan mikro-społecznej stabilności lub niestabilności. Tym samym sposób przynależności do wspólnego świata społecznego nie przejawia się ani w oficjalnym porządku instytucjonalnym, ani w strukturach wiedzy abstrakcyjnej. Jeśli bowiem chłopi nie notują zwiększonych zysków nawet w czas obfitych zbiorów - jak powiada M. Foucault, a całość ich pracy, niepodparta żadnym zabezpieczeniem prócz wiary religijnej, zostaje wystawiona na kapryśność sił przyrody i jeszcze bardziej nieprzychylnych im rynków, to siłą rzeczy świat chłopa różni się od świata przedsiębiorczego mieszczanina. Tam, gdzie pierwszy zdany jest na łaskę Boga, drugi może racjonalnie planować inwestycje lub 
w trosce o własne dobra powstrzymywać się od nich. Tam, gdzie pierwszy patrzy na uspołecznioną naturę z bojaźnią i drżeniem, drugi dostrzega w niej bezpieczny obszar działania i przestrzeń dla własnej emancypacji. Stąd też bezpośrednie doświadczenie świata albo daje się wpisać w porządek ufundowany instytucjonalnie, zawierający w sobie zbiór ściśle określonych reguł, które łączą ze sobą rynki, produkcję rolną, administrację publiczną, systemy wiedzy naukowej, warunki klimatyczne itd., albo jest stabilizowane na poziomie religijnym, delegując $\mathrm{w}$ ten sposób ową bezpośredniość $\mathrm{w}$ obszar teologicznie rozpoznawanego zrządzenia losu. Można powiedzieć, że natura przeciwstawia się woli chłopa, mieszczanin $\mathrm{z}$ kolei $\mathrm{w}$ naturze odnajduje zasadę działania swojej wolnej woli. Zarówno mieszczanin, jak i chłop dysponują określonym zestawem praktyk i aktywności, które z jednej strony podtrzymują delikatną tkankę poszczególnych mikroświatów, budując ich odrębną codzienność, z drugiej zaś tworzą szerszy kontekst życia społecznego jako całości, pozwalający zachować jego jedność. Nie jest to jednak syntetyczna jedność rozumu, lecz ontologiczny splot dokonujący się w procesach stabilizowania relacji współzależności.

Problematyka przypadku i konieczności dotyczy zatem wymiaru praktycznego. Nie można oddzielić nauki od państwa, techniki inżynieryjnej powodującej zwiększoną wydajność młynów w całym kraju od rachunku ekonomicznego, wszystkie te obszary są ze sobą splątane i wytwarzają określone relacje społeczne. W tym sensie konieczność nie tkwi w rzeczywistości w sposób niemy i „globalny”, czekając tylko na odpowiednią epistemologię, która umożliwi jej wydobycie za pomocą abstrakcyjnych pojęć. Konieczność dokonuje się na wielu poziomach złożoności społecznej. Ta z kolei, rozumiana jako nieustanny proces splątywania odmiennych światów życia, często krąży po drogach, które przekraczają zdolności rozumienia nie tylko określonych grup społecznych, ale również dysponującej środkami kontroli i nadzoru administracji państwowej. W tej kwestii złożoność działania społecznego znacznie wyprzedza myślenie o tym, co społeczne. Słowem tempo oraz skala dokonujących się zmian w XVIII-wiecznej Francji znacznie przekraczają sposób ich rozumienia. 


\section{Niestabilność polityczna i rozkwit świata wewnętrznego}

Administracja polityczna, korzystająca chętnie z nowoczesnych systemów wiedzy naukowej, skutecznie socjalizowała ryzyko związane z nieprzewidywalnością zjawisk naturalnych, niejako delegując je w najsłabsze obszary życia społecznego, przy jednoczesnym zawłaszczeniu zysków, będących z kolei efektem stabilizowania przypadku $\mathrm{w}$ innych obszarach życia społecznego. Stąd też w procesie kształtowania się świata mieszczańskiego można dostrzec stopniowe dopasowywanie się dyspozycji praktyczno-poznawczych do wymogów obiektywnych. Ta kompatybilność pozwalała na wpisywanie własnych oczekiwań, szans oraz działań w szeroki kontekst rzeczywistości społecznej jako ontologicznie stabilnego świata, gdzie poziom oficjalnego instytucjonalizowania przypadku splatał się z praktycznym wymiarem życia codziennego jako racjonalnych sposobów radzenia sobie z rzeczywistością.

Dla pojawiającego się w XVIII wieku mieszczaństwa, które dzięki określonym rozwiązaniom politycznym mogło się szybko bogacić, samo prawo nie gwarantowało jednak w dostatecznym stopniu bezpieczeństwa dla akumulacji kapitału. Prawo wydawane decyzją suwerena posiadało bowiem charakter arbitralny i nie opierało się na żadnym obiektywnie obowiązującym zbiorze reguł. Było raczej polem dowolności niż obszarem zapewniającym przewidywalność. Prawo stawało się tym bardziej niestabilne i odsłaniało swe arbitralne - historycznie przypadkowe - oblicze, im bardziej stabilizowanie natury sprzyjało potęgowaniu złożoności społecznej, a tym samym destabilizacji porządku państwowego. $\mathrm{W}$ tym sensie prawo polityczne mogło być postrzegane jako bardziej nieprzewidywalne niż nieprzewidywalna natura.

[B]urżuazja pozbawiona była nie tylko realnego wpływu na zarządzanie budżetem państwa, lecz jakichkolwiek gwarancji finansowych. Często więc zdarzało się tak, że z powodu arbitralnych decyzji króla bogacze tracili cały swój majątek [...] zdobyty dzięki spekulacjom. Totalnym bankructwom w świetle prawa towarzyszyły skrzętnie maskowane bankructwa częściowe i inne machinacje finansowe. $\mathrm{Z}$ pełnomocnictwa suwerena anulowano zawarte przez państwo kontrakty, zaprzestano wypłacać renty [...]. Jednocześnie państwo rozporządzało pieniędzmi, które było dłużne arystokracji finansowej. Co więcej, mogło arbitralnie - a więc całkiem niemoralnie - pozbawić swoich koordynatorów ich kapitału ${ }^{11}$.

${ }^{11}$ R. Koselleck, Krytyka i kryzys, przeł. J. Duraj, M. Moskalewicz, Warszawa 2015, s. 148. 
Ludwik XV mawiał, że „naród mój stanowi jedność ze mną, a prawa i interesy narodu, które niektórzy ośmielają się oddzielić od monarchy, są $\mathrm{z}$ natury złączone $\mathrm{z}$ moimi i spoczywają $\mathrm{w}$ moim ręku" ${ }^{12}$. Biorąc pod uwagę rosnącą złożoność struktur społecznych, liczne powiązania, jakie powstały pomiędzy szeroko rozumianą nauką, administracją państwową, naturą a życiem codziennym zwykłych ludzi, władza polityczna skupiająca się wyłącznie w rękach jednego człowieka, uczyniła owe powiązania czymś niezwykle kruchym i konfliktogennym. Taki system polityczny przeciwstawiał się naturze ludzkiej - jak zgodnie twierdzili Rousseau, Wolter oraz Diderot. Monarchia absolutna modernizowała rzeczywistość społeczną, zapewniając sobie określone profity przy jednoczesnym utrzymywaniu rozbudowanego aparatu ucisku oraz cenzury, który dostosowany był do struktury społeczeństwa feudalnego. Procesy modernizacyjne dokonujące się w ramach systemu absolutystycznego prowadziły jednak do szybkiego rozpadu wspólnot tradycyjnych, opierających się na więziach lokalnych i emocjonalnej solidarności. Władza z kolei nie potrafiła zaproponować żadnych nowych form przynależności społeczno-politycznej. Polityczne formy integrowania coraz bardziej współzależnych od siebie grup społecznych, nie mogły więc dłużej opierać się na zasadzie poddaństwa i sile przemocy.

Dla społeczeństwa mieszczańskiego, którego władza ekonomiczna i kulturowa stawała się coraz większa, państwo tworzyło podstawę do systematycznego gromadzenia kapitału, niwelując ryzyko związane ze „zdarzeniami rzadkimi”. Z drugiej strony ta względna niezależność od kaprysów natury była okupiona całkowitą zależnością od polityki prowadzonej przez króla i jego administrację. Można zatem powiedzieć, że znaczenie ekonomiczne oraz intelektualne świata mieszczańskiego było odwrotnie proporcjonalne do wpływu na kształt polityki i zarządzania państwem. Znaczy to, że mieszczaństwo pozbawione było możliwości politycznego intensyfikowania własnych korzyści. W świadomości mieszczańskiej charakter decyzji suwerena przybierał więc niekiedy postać naturalnej plagi, uspołeczniona natura zaś stawała się nieoczekiwanie stabilną rzeczywistością, podstawą do planowania określonych działań i przewidywania potencjalnych zysków, czyli tego, co Max Weber nazwałby racjonalnością. Dlatego też mieszczaństwo, w przeciwieństwie do szlacheckiej arystokracji czy duchowieństwa, nie musiało wiązać własnych sukcesów biznesowych czy intelektualnych osiągnięć z określoną

${ }^{12}$ Cytat za: G. Sorel, Złudzenia postępu, przeł. E. Breiter, Kraków 2015, s. 87. 
pozycją w hierarchii społecznej oraz stosunkiem do władzy państwowej. Mogło natomiast ów sukces odnosić bezpośrednio do własnej, refleksyjnie ugruntowanej działalności, kontestując tym sam szereg zapośredniczeń społecznych, które paradoksalnie umożliwiały jej tę kontestację.

Dla świadomości mieszczańskiej proces modernizacji skutkuje zatem radykalnym rozdzieleniem świata zewnętrznego, czyli świata praw politycznych oraz bezpośrednich relacji społecznych, od świata wewnętrznego, czyli świata, który Hegel w Fenomenologii ducha nazywa „refleksyjnym kierowaniem się ku sobie”. Znakomicie wyraził tę różnicę na krótko przed Heglem baron Paul Holbach w swoim Systemie przyrody: „Wskutek nieznajomości swojej własnej natury, swoich dążności potrzeb i praw, człowiek stracił w społeczeństwie wolność i popadł w niewolę. Nie doceniał potrzeb własnego serca albo uważał, że musi je tłumić i poświęcać swoje szczęście dla kaprysów władców"13. W tym sensie rozkwit świata wewnętrznego staje się swoistego rodzaju splotem społecznych warunków, który, podobnie jak później siła pary czy informatyzacja, przekształci zarówno stosunki społeczne, jak i sposoby myślenia o tych stosunkach.

Wróćmy jeszcze na chwilę do Heglowskiej diagnozy:

Świat wyobcowanego od siebie ducha - świat tego ducha rozpada się na dwa światy; pierwszy to świat rzeczywistości, czyli wyobcowanie ducha jako takie, drugi zaś to świat, który duch, wznosząc się ponad swój pierwszy świat, buduje sobie w eterze czystej świadomości [...]. Duchem tego świata jest przeniknięta przez samowiedzę istota duchowa, która zna siebie jako bezpośrednią obecną w teraźniejszości, tę oto istniejąca dla siebie, a istotę - jako pewną rzeczywistość sobie przeciwstawną [...]. Świat ten, chociaż jest światem, który powstał dzięki indywidualności, jest dla samo-wiedzy czymś bezpośrednio wyobcowanym i ma dla niej formę rzeczywistości nieulegającej zmianie ${ }^{14}$.

Samo-eksterioryzacja świadomości mieszczańskiej skutkuje określoną formą wiedzy na temat tego, co tej świadomości się przeciwstawia. W tym sensie wiedzę o tym, co społeczne charakteryzują dwie, fundamentalne w moim przekonaniu cechy. Są to autonomia oraz indywidualizacja. Autonomia wyraża radykalny dystans wobec świata społecznego, co jednocześnie umożliwia uchwycenie tego świata za pomocą pojęć jako przeciwstawnej całości. Indywidualizacja z kolei określa zsubiektywizowany wymiar wiedzy

${ }^{13}$ P. Holbach, System przyrody, przeł. J. Jabłońska, H. Suwała, Warszawa 1977, t. I, s. 58.

${ }^{14}$ G. W. F. Hegel, Fenomenologia ducha, przeł. Ś. F. Nowicki, Warszawa 2010, s. 317. 
o tym, co społeczne, który dzięki autonomii umożliwia szereg społecznie określonych zabiegów obiektywizacji - na przykład takich, jak status uczonego czy instytucja uniwersytetu. Autonomia oraz indywidualizacja łącznie i na poziomie kognitywnym zarysowują więc pole metody transcendentalnej. Jednakże „przestrzeń doświadczenia” oraz „horyzont oczekiwan’" ${ }^{15}$, jaki zarysowuje się $\mathrm{w}$ ramach procesu samo-eksterioryzacji, nie rozmijają się ze sobą - jak chcieliby tego Hegel i Koselleck. Wręcz przeciwnie, są one wobec siebie kompatybilne. Heglowska sprzeczność wyraża tu jedynie pragnienie intensyfikacji tej kompatybilności na wielu poziomach życia społecznego.

\section{Autonomizacja i indywidualizacja, czyli o społecznym konstruowaniu rozumu}

Polityczna stabilizacja natury $\mathrm{w}$ ramach porządku absolutystycznego umożliwia zamożniejszym warstwom mieszczaństwa wpisywanie własnego doświadczenia rzeczywistości w przewidywalny obszar zdarzeń. W ten sposób zabezpieczony zostaje czas, w takim sensie, że więź między teraźniejszością a przyszłością staje się ontologicznie uspójniona, tak jak więź pomiędzy produkcją a reprodukcją, zarabianiem pieniędzy a inwestowaniem, działaniem a planowaniem, pojęciem a jego empirycznym obrazem. Tak skonstruowana przewidywalność zmniejsza presję warunków społeczno-ekonomicznych, które wcześniej przymuszały ludzi do tego, by całą swoją uwagę oraz czas poświęcali sztuce utrzymania się przy życiu. Stosunek do świata jako stosunek poznawczy zaczyna więc przybierać charakter „odczasowionej” teorii, która konstytuuje się poza relacjami, jakie zachodzą między ludźmi, czy też szerzej - grupami społecznymi. Refleksyjne kierowanie się ku sobie - to otwarcie pola transcendentalnego, jak powiada w Słowach i rzeczach M. Foucault - znajduje na swej drodze do świata tylko siebie i z tak określonego stosunku do siebie wyprowadza sposób ustosunkowywania się do rzeczywistości społecznej. Pozwalało to na systematyczne wytwarzanie określonych kompetencji praktycznych, takich jak przewidywanie, zarządzanie czy też, ogólniej rzecz ujmując, racjonalne planowanie działań, dla których podstawą staje się refleksyjne odniesienie do własnych zamierzeń i motywacji. Dopiero

${ }^{15}$ R. Koselleck, Przestrzeń doświadczenia, horyzont oczekiwań, [w:] tenże, Semantyka historyczna, przeł. W. Kunicki, Poznań 2012, s. 357-387. 
w politycznie ustabilizowanych warunkach egzystencji, które w codziennym odczuciu stają się czymś naturalnym i do tego stopnia powszednim, że znikają z pola refleksji, człowiek może zacząć myśleć o sobie jak o rezultacie swojego wolnego, całkowicie autonomicznego wyboru. Zawieszając bowiem szereg współzależności ekonomiczno-społecznych, takich jak społeczny podział pracy, prawo własności czy konsumowanie zysków, myślenie o społecznych warunkach możliwości samego myślenia możemy wziąć w nawias jako coś, co przestaje być widoczne.

Oni - pisze o stanie średnim David Hume - tworzą najliczniejszą warstwę społeczną, o której można przypuścić, iż jest wrażliwa na filozofię, a przeto wszelkie rozprawy moralne winne być w głównej mierze do nich kierowane. Możni nazbyt nurzają się w rozkoszach, biedaków zaś nazbyt zaprząta zaspokajanie potrzeb życiowych, by wsłuchać się w cichy głos rozumu ${ }^{16}$.

Wszelkiego rodzaju pracę intelektualną bardzo łatwo więc daje się zinterpretować w kategoriach bezpośredniej ekspresji, na przykład jako mówienie, pisanie, malowanie, obserwowanie itd. W ten sposób samo rozumienie rzeczywistości staje się z jednej strony zależne od czynników subiektywnych, z drugiej zaś coraz bardziej splata się z takimi zjawiskami, jak zabieganie o status społeczny, akumulacja kapitału, czas wolny, przynależność klasowa, dostęp do edukacji, za którą trzeba słono płacić itd. „Pojawienie się rozumu powiada P. Bourdieu - jest nierozerwalnie związane ze stopniowym uniezależnianiem się od społecznych mikrokosmosów zbudowanych na przywilejach, w których stopniowo wynajdywano teoretycznie uniwersalne, ale praktycznie zmonopolizowane sposoby myślenia i działania" ${ }^{17}$.

${ }^{16} \mathrm{D}$. Hume, O stanie średnim: http://www.nowakrytyka.pl/spip.php?article463 [dostęp: 31.03.2017]. Warto tutaj zaznaczyć, że radykalny relatywizm D. Hume co do kwestii konieczności nie jest aż tak radykalny, jakby się wydawało: „Hume rozprawił się z pojęciem naturalnej konieczności i tym samym zniszczył metafizyczne spoiwo utrzymujące dotąd obiektywny świat jako logicznie powiązanych relacji, faktów i wydarzeń. Jednakże nawet on nie pragnął podważyć przyjętych wzorców tych powiązań; chciał jedynie przenieść je w wymiar empiryczny, zamieniając je z konieczności a priori w prawdopodobieństwo de facto". (I. Berlin, Rzekomy relatywizm w XVIII wiecznej myśli europejskiej, przeł. H. Hardy, [w:] tenże, Pokrzywione drzewo człowieczeństwa, Warszawa 2004, s. 63). Jeśli chodzi zaś o antropologię filozoficzną, D. Hume nie jest w ogóle relatywistą. Jest zdania, że natura ludzka nie ulega zmianie co do swych istotowych cech.

${ }^{17}$ P. Bourdieu, Medytacje pascaliańskie, przeł. K. Wakar, Warszawa 2006, s. 112. 
Relacja, jaka zaczyna łączyć mieszczaństwo z uspołeczniona naturą, kontrastuje również z rozpadem tradycyjnych więzi społecznych. Rozrastający się rynek, zwiększona mobilność jednostek, nowy podział pracy społecznej, a tym samym rosnąca współzależność różnych grup sprawia, że relacje pomiędzy ludźmi stają się coraz bardziej anonimowe, a tym samym coraz bardziej nakierowane na interes osobisty. Rozpadały się również korporacje handlowo-rzemieślnicze, które potrafiły utrzymywać poziom solidarności zawodowej w obrębie lokalnych społeczności. Charakter i znaczenie tych "przed-nowoczesnych” korporacji opisuje Emil Durkheim w takich oto słowach: „Emanuje z nich ciepło, które ogrzewa lub rozbudza serca, otwiera je na sympatię, roztapia każdy egoizm"18. Konsekwencje rozpadu lokalnych wspólnot w wyniku podłączenia ich do szerszego wymiaru społeczno-ekonomicznych zależności najtrafniej chyba opisali K. Marks i F. Engels w Manifeście komunistycznym:

Burżuazja pozrywała bezlitośnie wielorakie więzy feudalne, które przywiązywały człowieka do jego naturalnego środowiska i nie pozostawiła pomiędzy ludźmi żadnego innego węzła prócz nagiego interesu, prócz wyzutej z wszelkiego sentymentu zapłaty gotówką. Świątobliwe dreszcze pobożnego marzycielstwa, rycerskiego zapału, mieszczańskiego sentymentalizmu zatopiła w lodowatej wodzie egoistycznego wyrachowania. Godność osobistą zmieniła w wartość wymiennąa ${ }^{19}$.

W przeciwieństwie do ustabilizowanej natury, świat społeczny staje się coraz bardziej niestabilny, złożony, skomplikowany, czy, jakby powiedział K. Marks, zapośredniczany przez rynek i pieniądz, wprowadzając tym samym ogólny niepokój w bezpośrednie relacje międzyludzkie. Stąd też najbardziej charakterystyczną cechą społeczeństw XVIII wieku jest ich „zewnętrzna” konfliktowość oraz „wewnętrzna” obłuda, czemu dał wyraz J. J. Rousseau w Rozprawie o pochodzeniu i podstawach nierówności między ludźmi:

Wszystko sprowadza się do pozorów, wszystko staje się podrobione i sztuczne, honor, przyjaźń, cnota, a często nawet i same występki, ile że został odkryty sekret czerpania z nich chluby; słowem, jak to ciągle drugich pytając, czym jesteśmy, a nigdy nie mając odwagi samych siebie o to zapytać, wśród całego tego zalewu filozofii, ludzkości, grzeczności, wzniosłych zasad mamy już tylko czcze

\footnotetext{
${ }^{18}$ E. Durkheim, O podziale pracy społecznej, przeł. K. Wakar, Warszawa 1999, s. 36.

${ }^{19}$ K. Marks, F. Engels, Manifest komunistyczny, przekł. zbiorowy, Warszawa 1949, s. 31.
} 
i zwodnicze pozory honoru bez cnoty, rozumu bez mądrości, przyjemności bez szczęścia ${ }^{20}$.

W zetknięciu z zapośredniczającą dynamiką rynków oraz abstrakcyjnymi systemami wiedzy naukowej, tradycyjne wspólnoty stają się niestabilne, wymuszając nowy, bardziej zindywidualizowany sposób uczestnictwa w życiu społecznym. Teoretyczną odpowiedzią na tak zastaną sytuację społeczną jest antropologia filozoficzna, kompensująca - jakby powiedział Odo Marquard - utratę dotychczasowego świata życia ${ }^{21}$. Człowiek zostaje więc sam na sam ze sobą, a jego wspólnota może mieć już tylko charakter abstrakcyjny. Jednakże proces indywidualizacji rozpatrywany jako nowy sposób uczestnictwa jednostek w życiu społecznym staje się również procesem socjalizacji, który właśnie od strony zindywidualizowanej formy uczestnictwa powinien znaleźć szereg uzasadnień teoretycznych ${ }^{22}$. Dwuznaczność zachodząca pomiędzy procesami socjalizacji i indywidualizacji będzie wyrażała się $\mathrm{w}$ wielu formach, w których chyba najbardziej transparentną w XVIII-wiecznej filozofii jest idea liberalizmu ekonomicznego ${ }^{23}$. Podkreśla ona wolność człowieka w zawiązywaniu relacji z innymi jednostkami, relacji, która zostaje całkowicie uwolniona z wszelkiego odniesienia do sfery wspólnotowej i wspólnego inte-

${ }^{20}$ J. J. Rousseau, Rozprawa o pochodzeniu i podstawach nierówności między ludźmi, przeł. H. Elzenberg, [w:] tenże, Trzy rozprawy z filozofii społecznej, Warszawa 1956, s. 229.

${ }^{21}$ Patrz: O. Marquard, Człowiek oskarżony $i$ uwolniony od odpowiedzialności, przeł. K. Krzemieniowa, [w:] tenże, Rozstanie z filozofia pierwszych zasad, Warszawa 1994.

${ }^{22}$ Istnieją różne sposoby indywidualizacji. Stosunek do siebie jest formą przekształcalną $\mathrm{w}$ różne sposoby bycia-w-świecie. M. Foucault w swoich pracach pokazuje, że procesy subiektywizacji zachodzące w starożytnej Grecji oraz w świecie chrześcijańskim (władza duszpasterska) zupełnie różnią się od tych, jakie przebiegają w świecie nowoczesnym. Od czasów Kartezjusza stosunek do siebie staje się warunkiem formalnym wszelkiej wiedzy, wszelkiego poznania (patrz: M. Foucault, Historia seksualności, przeł. T. Komendant, Gdańsk 2010).

${ }^{23}$ Jak zauważa R. Koselleck, pojęcie ekonomii w XVIII wieku ulegało całkowitemu przeobrażeniu: „To konkretne, nasycone doświadczeniem, ograniczone pojęcie ekonomii uległo od XVIII stulecia rozszerzeniu, zostało niejako zdogmatyzowane za sprawą A. Smitha. Ekonomia wyodrębniła się z arystotelesowskiej triady etyki, ekonomii i polityki, utrwaliła się różnicująco jako samodzielny obszar, kierującego się czystym interesem, możliwego, teraz do określenia jako nowoczesne społeczeństwo obywatelskie. Ekonomia odnosi się od tej pory do większego, do terytorialnego, państwowego, narodowego, a w końcu do światowego usieciowania potrzeb i do ciągłego ich wzrostu; jest obszarem ponadpaństwowego, zależnego od kapitału, dynamizowanego nauką i techniką społeczeństwa przemysłowego." (R. Koselleck, U. Spree, W. Steinmetz, Trzy obywatelskie światy, przeł. W. Kunicki, s. 471-472, [w:] tenże, Semantyka historyczna, Poznań 2012). 
resu. Obok liberalizmu ekonomicznego można również postawić koncepcję pełnej autonomii moralnej, która jak w przypadku teorii I. Kanta nie znajduje dla siebie środków urzeczywistnienia w postaci instytucji społecznych czy politycznych. Stąd też filozofia antropologiczna oraz nauki ekonomiczne stanowią najbardziej wyalienowane ze świata społecznego formy namysłu o świecie społecznym.

Oświeceniowa fascynacja doświadczeniem siebie nie jest zatem wyrazem dziejowo koniecznej emancypacji ludzkiego ducha, tryumfem samoświadomości nad religijnym zabobonem, ale procesem społecznym. Postawa refleksyjnego kierowania się ku sobie, wyrażająca się najpełniej w procesach autonomizacji oraz indywidualizacji intelektualnej, uznaje tym samym struktury inkorporowane za swoje własne „czyste” dyspozycje, nie rozpoznając przy tym faktu, że to od stopnia, w jakim podlega się politycznym procesom dystrybucji i cyrkulacji nieudanej konieczności, zależy wytworzenie pozycji neutralnej wobec tych właśnie procesów. Zbieżność struktur inkorporowanych ze strukturami obiektywnymi „rodzi złudzenie bezpośredniego pojmowania - powiada P. Bourdieu - charakterystycznego dla praktycznego doświadczania świata bliskiego, i zarazem wyklucza też z tego doświadczenia zapytywanie o jego własne warunki możliwości”24. Dlatego też politycznie ustabilizowana natura w świadomości mieszczańskiej inteligencji jednocześnie transcenduje, ulega uwewnętrznieniu oraz odczarowaniu ${ }^{25}$. Na ontologiczny proces uspołeczniania natury mieszczaństwo odpowiada więc epistemologiczną naturalizacją tego, co społeczne.

Wobec rozpadających się wspólnot tradycyjnych i braku nowych form przynależności politycznej natura jawi się jako wyróżniony obszar doświadczenia, gwarantujący stały punkt oparcia dla realizacji własnych możliwości. W ten sposób natura nie tworzy jednak jednolitego uniwersum dla wszystkich, zarówno na poziomie epistemologicznym, jak i ontologicznym. Przykład z niedoborem żywności wskazuje raczej na złożoność rzeczywistości społecznej, która nie stanowi syntetycznej jedności na mocy samego rozumu, lecz odnosi się do procesów splątywania poszczególnych światów społecznych siecią realnych zależności ekonomicznych, politycznych, kulturowych itd. Każdy z tych światów charakteryzuje się specyficznym dla siebie doświadczeniem rzeczywistości oraz tego, co społeczne, jako pewnej jedności. Dlatego też żadna postawa nie odzwierciedla jedynie słusznego sposobu

\footnotetext{
${ }^{24}$ P. Bourdieu, Zmysł praktyczny, przeł. M. Falski, Kraków 2008, s. 36.

${ }^{25}$ Patrz: B. Latour, Polityka natury, przeł. A. Czarnacka, Warszawa 2009.
} 
przynależności do świata, gdyż to właśnie ów sposób wytwarza dopiero obszar społecznie określanych ograniczeń i możliwości logicznych rozumienia świata jako takiego.

Pojęcie autonomii oraz indywidualizacji wiąże się bezpośrednio z poziomem epistemologii, badaniem logicznych warunków możliwości poznania. Stąd też pojawienie się świata społecznego jako przedmiotu poznania polega głównie na tym, aby ów świat $\mathrm{z}$ tego przedmiotu jak najszybciej i najskuteczniej wyrugować. Za F. Nietzsche można powiedzieć, że „logika wydaje się konieczną jak chleb i woda, lecz też jak one strawą więzienną, jeśli ma się ją spożywać samą tylko, bez niczego"26. Tym samym praca intelektualna staje się predestynowana do tego, by postrzegać własne produkty jako realizację uprzednio ustanowionej autonomii, zawieszającej wszelkie możliwe formy społecznego zaangażowania oraz materialnego $\mathrm{w}$ nim usytuowania. W ten sposób wytwory oraz wytwórcy dóbr symbolicznych, których zwie się intelektualistami i uczonymi, budują swoistego rodzaju monopol na wypowiadanie się o świecie społecznych praktyk:

Mogąc stopniowo uwalniać się od elementarnych trosk materialnych, zwłaszcza dzięki zyskom z bezpośredniej lub pośredniej sprzedaży wiedzy praktycznej przedsiębiorstwom komercyjnym lub państwu, i mogąc zgromadzić dzięki swojej pracy i dla jej potrzeb umiejętności, stanowiące potencjalny kapitał kulturowy, nowi aktorzy społeczni stawali się coraz bardziej skłonni, a także coraz bardziej zdolni do potwierdzania swojej osobistej i zbiorowej niezależności od władzy ekonomicznej i politycznej, która potrzebowała ich usług (i w stosunku do arystokracji opartej na urodzeniu, której przeciwstawiali swoją pozycję opartą na zasługach i coraz częściej także na talencie) ${ }^{27}$.

Praca intelektualna tworzy swój własny przedmiot tego, co społeczne, znajdując w samej sobie zasadę rozumienia i wyjaśniania tego przedmiotu. Czysta myśl uczonych jest teodyceą ich własnego uprzywilejowania.

Dlatego też intelektualna warstwa mieszczaństwa poprzez refleksyjne kierowanie się ku sobie nie rozpoznaje sama siebie jako części określonej wspólnoty, klasy czy też grupy. Samo-eksterioryzacja, która w rzeczywistości oznacza kompatybilność pomiędzy dyspozycjami a warunkami obiektywnymi jako postawa poznawcza odzwierciedla uniwersalną możliwość antropologiczną. W ten sposób mieszczaństwo, odwołując się do rozumu, może

\footnotetext{
${ }^{26}$ F. Nietzsche, Wiedza radosna, przeł. L. Staff, Kraków 2004, s. 78.

${ }^{27}$ P. Bourdieu, Medytacje pascaliańskie, przeł. K. Wakar, Warszawa 2006, s. 34-35.
} 
troszczyć się o swoje interesy oraz teoretycznie je uzasadniać w wysublimowanym języku abstrakcji, zupełnie tak, jakby tego nie robiło, to znaczy tak, jakby w samym tym działaniu realizowało jedynie naturalny sposób bycia-w-świecie. W tym sensie cele i motywacje działalności indywidualnej znajdują swoje najgłębsze uzasadnienie w bezpośredniej samo-wiedzy. Stąd też mieszczaństwo chętnie widzi siebie nie jako klasę, grupę, czy też dowolnie rozumiany kolektyw, lecz jako emanację człowieka naturalnego, człowieka jako takiego. Mieszczaństwo jako antropologiczny typ idealny wprost unika wszelkich afiliacji, przynależności oraz uwikłań, jest czystym kierowaniem się myślenia ku sobie, samą naturą człowieka, uznającą logiczną konieczność takiego ruchu: „człowiek społeczny nie jest człowiekiem naturalnym: należy go więc ukształtować inaczej - i któż nada mu owo nowe istnienie, jeśli nie on sam"28 - powiada Rousseau.

\section{Logika rozumu i symetria}

Ostatecznie u progu XVIII wieku w myśleniu o tym, co społeczne powoli zarysowuje się wyraźna dystynkcja, swoistego rodzaju nieciągłość pomiędzy uprawianiem nauki a codzienną praktyką życia, autonomią a zaangażowaniem, prawdą a rzeczywistością. Ten podział prowadzi - jak mi się zdaje - do dwóch podstawowych konsekwencji.

Po pierwsze to, co można pobieżnie nazwać instytucjonalizacją abstrakcji, wyraża się w procesach dopasowywania dyspozycji praktyczno-teoretycznych do obiektywnych wymogów rzeczywistości, kreując nowych aktorów, jakimi są intelektualiści oraz uczeni. Ta kompatybilność sprawia, że społeczne warunki możliwości konceptualizacji tego, co społeczne stają się niewidoczne, umożliwiając tym samym spoglądanie na świat społeczny z lotu ptaka. W ten sposób czyste dyspozycje będące efektem ustrukturyzowania w ramach społecznie określonych praktyk, stają się również tym, co strukturyzujące. Uzyskują swoją moc sprawczą - czy też jakby powiedział R. Koselleck, konstytuują władzę pośrednią - dzięki rozrastającej się sferze publicznej ${ }^{29}$.

\footnotetext{
${ }^{28}$ J. J. Rousseau, Emil, czyli o wychowaniu, przeł. W. Husarski, Wrocław 1955, t. II, s. 350.

${ }^{29}$ Patrz: J. Habermas, Strukturalne przemiany sfery publicznej, przeł. W. Lipnik, M. Łukasiewicz, Warszawa 2006.
} 
Niech więc nie dziwi fakt, że lokalne zdarzenia, zaobserwowane tendencje, odczucia, osobiste doświadczenia czy diagnozy dotyczące świata społecznego oświecony rozum będzie konstatował jako abstrakcyjne charakterystyki totalne. Na przykład w Umowie społecznej J. J. Rousseau wychodzi z założenia, że analiza praw nie może zasadzać się na empirycznie ustalonych faktach, gdyż te sprzyjają tyranom. „Stałym sposobem jego rozumowania - Rousseau odnosi się tu do Hugo Grocjusza - jest oparcie prawa na faktach. Można by zastosować metodę bardziej konsekwentną, ale mniej przychylną dla tyranów"30. Stąd w swoich pismach szuka on uzasadnienia dla nowej formy uporządkowania życia społecznego poza uwarunkowaniami aktualnej polityki, czyli w autonomicznym obszarze refleksji, który nie znajduje swojego zakorzenienia ani w lokalności życia społecznego, ani społeczeństwie jako takim, lecz w jego negacji jako całości. Rezultat takiego projektu jako formy wiedzy jawić się musi z konieczności jako uniwersalny. Uniwersalność polega tu na wyłożeniu określonych zasad myślenia, które same w sobie znajdują ugruntowanie dla własnych racji. Jak zauważa Jean Starobinski: „Zasada bowiem jest słowem początku, wypowiedzią stanowiącą, która chce zawierzyć i utrwalić w sobie radosny autorytet źródła" ${ }^{31}$. Wówczas wszelkie procesy oraz struktury cząstkowe zachodzące $\mathrm{w}$ społeczeństwie stają się widoczne dopiero z perspektywy jego syntetycznej całości, którą gwarantuje rozum. Dla rozumu społeczeństwo jest zatem przedmiotem zrozumiałym dopiero jako całość pojęciowa, czyli w pełni homogeniczna. Stąd też, jak pisze P. Bourdieu, „projekt ustalenia obiektywnych regularności (struktur, praw, systemów relacji itd.) niezależnych od indywidualnych świadomości i woli, wprowadza nieciągłość wytyczoną pomiędzy poznaniem uczonym a poznaniem praktycznym, uznając za »racjonalne«, "pojęcia wrodzone« bądź »ideologie« mniej lub bardziej jawne wyobrażenia" ${ }^{32}$. Uosobieniem zinstytucjonalizowanej abstrakcji jest uczony. Nie musi on dzielić swojego losu z mieszkańcami platońskiej jaskini, lecz może zostać ich prawodawcą.

Po drugie, wynikiem dystynkcji pomiędzy uprawianiem nauki a codzienną praktyką życia, autonomią a zaangażowaniem, prawdą a rzeczywistością jest krytyczna władza rozumu:

\footnotetext{
${ }^{30}$ J. J. Rousseau, Umowa społeczna, przeł. A. Peretikowicz, Kęty 2007, s. 12.

${ }^{31}$ J. Starobinski, Emblematy rozumu, przeł. M. Ochab, Warszawa 1997, s. 26-27.

${ }^{32}$ P. Bourdieu, Zmysł praktyczny, przeł. M. Falski, Kraków 2008, s. 36.
} 
Prawdy, o którą zabiega krytyka, należy bowiem szukać w przyszłości. Dlatego nawet jeśli bezstronne roszczenia są rzeczywiście siłą napędową procesu krytyki, to $\mathrm{z}$ definicji proces ten nigdy się nie kończy. Ponieważ krytyk jest przywiązany do prawdy, którą należy dopiero odkryć, proces krytyki siłą rzeczy jest permanentny [...]. Zassany w wir przyszłości krytyk traci grunt pod nogami swoją teraźniejszość. W tych okolicznościach nie pozostaje mu nic innego jak tylko uczynić z postępu swój sposób bycia ${ }^{33}$.

\section{Z kolei Bronisław Baczko pisze:}

Uczestnictwo $\mathrm{w}$ procesie krytyki filozoficznej oznacza realizację powołania moralnego uczonego i filozofa, a „krytyk filozoficzny” ma stać się przewodnikiem pozwalającym w historii - ale i w życiu współczesnym - odróżnić prawdę od opinii, prawo od władzy, obowiązek od korzyści, cnotę od sławy. Ta względna autonomizacja postawy krytycznej [...] utwierdza optymistyczną wizję historiozoficzną współczesności, rozpatrywanej ze względu na nieuchronne i postępujące zwycięstwo rozumu nad przesądem, religią itd. ${ }^{34}$

Krytyczna władza rozumu stanowi więc gwarant dystynkcji, którą z góry zakłada i potwierdza, skoro nie znajduje swoich podstaw w aktualnie empirycznej rzeczywistości. Stosunek rozumu do przyszłości wyraża się zatem $\mathrm{w}$ procesach kolonizowania wielości światów życia, które pozostają poza kontrolą „racjonalnych” struktur.

Pojawia się w ten sposób problem praktyczny - nazwijmy go roboczo oświeceniowym projektem emancypacji - mający na celu całkowite przekształcenie rzeczywistości społecznej, zgodne z wymogami rozumu. Jeśli praca abstrakcji oraz praca krytyki są ze sobą skorelowane na poziomie kognitywnym, to ów problem można wyrazić w formie pytania: w jaki sposób ponownie powiązać rozdzielone od siebie dziedziny poznania i polityki, wiedzy i świata społecznego, autonomii i zaangażowania, prawdy i rzeczywistości?

Jednakże prawdziwy problem polega na tym, że te radykalnie oddzielone od siebie dziedziny pozostają ze sobą splątane na wiele sposobów i na wielu poziomach, których autonomiczny rozum nie jest w stanie już dostrzec. Praca abstrakcji oraz praca krytyczna oznaczają nowy sposób generowania związków z historią i rzeczywistością społeczną. Polega on na tym, że mówienie

\footnotetext{
${ }^{33}$ R. Koselleck, Krytyka i kryzys, przeł. J. Duraj, M. Moskalewicz, Warszawa 2015, s. 245-246.

${ }^{34}$ B. Baczko, J. J. Rousseau, Samotność i wspólnota, Warszawa 1964, s. 82-83.
} 
o tym, co społeczne, zakłada zawieszenie społecznych warunków możliwości $\mathrm{w}$ porządku konstruowania teorii. Ten ruch wprawdzie pozwala na systematyczną organizację wypowiedzi, a tym samym formowanie się określonych dziedzin przedmiotowych, takich jak ekonomia, prawo, historia, polityka, antropologia itd., ale dzieje się to kosztem pytania o ontologiczne podstawy tego założenia. W ten sposób nawet dziś wielu historyków zapomina w swej pracy o własnej historyczności, podobnie jak wielu socjologów zapomina o tym, że należą do świata, który opisują i że są w nim w określony sposób usytuowani. Ta amnezja teoretyczna, będąca strukturalnie wpisana niemal w każdą praktykę badawczą, tłumaczy łatwość, z jaką uczone umysły epoki Oświecenia mogły zawieszać społeczno-ekonomiczne warunki własnej egzystencji w ramach swej pracy intelektualnej, obdarzając na równi wszystkich ludzi rozumem i zdolnością do samostanowienia, oraz łatwość, z jaką w tym samym ruchu odbierali niemal wszystkim te przymioty. Znakomicie uchwycił tę sprzeczność Stanisław Ossowski:

Prawa głosiły wolność dla wszystkich, ale nie dotyczyły zapewnienia wszystkim ludziom środków do wykorzystania tej wolności, tak że wolność nie zagrażała dominacji klasy, która dysponowała koniecznymi środkami ekonomicznymi [...]. Zwolennicy swobód demokratycznych jako takich zamykali oczy na istniejące przymusy ekonomiczne, bardziej złożone w działaniu, choć mniej krępujące niż przymus fizyczny ${ }^{35}$.

Praca abstrakcji i krytyki wytycza sposób formowania teorii, które powszechnie uchodzą za język uprzywilejowany, a którego źródło rozumienia zaczyna się i kończy w obrębie instytucji naukowych oraz dyskursów eksperckich. Dlatego rozumienie wszelkich konfliktów politycznych w ramach oświeconego rozumu przybiera postać błędnego koła, w którym podstawą staję się wyznaczenie teoretycznej czystości jako kontinuum jedynej możliwości pogodzenia, a tym samym zniesienia samego konfliktu. W tym sensie każda strategia emancypacji musi stać się nieodłącznym elementem totalizującej wizji bytu i historii. Pomyślmy w tym miejscu choćby o kobietach, a raczej ich nieobecności w humanistycznym procesie emancypacji oświeceniowej, albo o zapomnianym przypadku haitańskiej rewolucji, dzięki któremu na nowo można odczytywać dziedzictwo Oświecenia ${ }^{36}$.

${ }^{35}$ S. Ossowski, Demokracja w świecie napięć politycznych, Warszawa 1951, s. 67.

${ }^{36}$ Patrz: S. Buck-Morss, Hegel, Haiti i historia uniwersalna, przeł. K. Bojarska, Warszawa 2014. 
Proces Oświecenia mógł więc pod pewnymi względami osiągać niesamowite efekty, dokonywać olbrzymiego postępu w wielu wymiarach, pod innymi jednak mnożył tylko sprzeczności, prowadząc do skutków przeciwnych od pierwotnie zamierzonych. W tym sensie refleksyjność kultury Oświecenia w warunkach wzrastających nierówności i rodzącego się systemu kolonialnego stawia pojęcie emancypacji, której podstawą ma być podmiotowa samo-wiedza uczonego, nie jako jedyne i właściwe rozwiązanie tej epoki, lecz jako problem praktyczny, którego nie należy tak po prostu poddawać krytyce i odrzucać, ale na nowo przemyśleć.

Postulat przekształcenia rzeczywistości społecznej, czyli pojednania prawdy i rzeczywistości, idzie tutaj ramię $\mathrm{w}$ ramie $\mathrm{z}$ uprawomocnieniem pozycji samego rozumu, czyli między innymi określonej pozycji naukowego mikroświata oraz systemów wiedzy naukowej. Hegel powiada tak: „Oświecenie [...] zna czystą jaźń świadomości jako absolutną i podejmuje walkę z czystą świadomością absolutnej istoty wszelkiej rzeczywistości [...]. Ta refleksyjnie ku sobie skierowana negatywność to pojęcie, będące prostą wiedzą, która zna samą siebie i zarazem swe przeciwieństwo, ale przeciwieństwo to zna w sobie jako zniesione" ${ }^{\prime 7}$. Paradoks polega jednak na tym, że umysł uczony - swoistego rodzaju wcielenie oświeconego rozumu - przykrawając rzeczywistość społeczną na swoje podobieństwo, rzeczywiście uznaje ją $w$-sobie jako zniesioną, podczas gdy w aspekcie praktycznym proces ten nie może dotyczyć całości świata społecznego. Dzieje się tak dlatego, że konieczność praw rozumu, którą uczony stara się narzucić światu, jest ze swej konieczności koniecznością nieudaną, która, jak pokazał przykład niedoboru żywności, raczej krąży, niż stanowi właściwy eter rzeczywistości, jest raczej projektowana, konstruowana i ontologicznie stabilizowana niż obowiązująca. W sensie kognitywnym zaś stanowi rezultat procesów wytwarzania oraz utrwalania przywilejów w obrębie określonych światów społecznych, w tym świata uczonych i ich instytucji.

Pola naukowe, owe mikrokosmosy, są pod pewnymi względami społecznymi światami jak wszystkie inne, w których występuje koncentracja władzy i kapitału, monopole, stosunki sił, egoistyczne interesy, konflikty itp. są również pod innym względem uniwersami wyjątkowymi, nieco cudownymi, w których konieczność rozumu w różnym stopniu ustanawia się w strukturach i dyspozycjach $^{38}$.

${ }^{37}$ G. W. F. Hegel, Fenomenologia ducha, przeł. Ś. F. Nowicki, Warszawa 2010, s. 352.

${ }^{38}$ P. Bourdieu, Medytacje pascaliańskie, przeł. K. Wakar, Warszawa 2006, s. 156. 
W ten sposób oświecony rozum jest zainteresowany w równym stopniu zniesieniem, co uprawomocnieniem dystynkcji pomiędzy polityką a poznaniem, wiedzą a praktyką, autonomią a zaangażowaniem, i w końcu prawdą i rzeczywistością. W czym przypomina trochę Heglowską postać świadomości nieszczęśliwej.

Od czasów Oświecenia umysł uczony stopniowo zaczyna przyzwyczajać się do zacierania śladów własnej pracy, tym samym wyznaczając sens oraz prawdę własnej działalności w obrębie niezaangażowanej myśli teoretycznej. Prawdziwym problemem nie jest tu tylko to, że wraz z procesami modernizacji następuje systematyczne poszerzanie się pola autonomii naukowej, lecz fakt, iż wraz z poszerzeniem autonomii ramię w ramię kroczy społecznie określona praktyka badawcza, która stworzyła systemy wiedzy naukowej zdolne funkcjonować obiektywnie. Co jednak oznacza ten podwójny ruch w praktyce? Jak zauważa Jerzy Kmita, systemy wiedzy naukowej zaczęly dostarczać różnym dziedzinom praktyki społecznej przesłanek do działania, które zaczęły wywoływać określone skutki ${ }^{39}$. Znaczy to, że nauka jest społecznie wytwarzana, ale jednocześnie wytwarza to, co społeczne w określonej postaci. Przykład dotyczący niedoboru żywności, jakiego dostarczył nam M. Foucault, wyraźnie pokazuje tę zależność. W ten sposób wracamy do samego początku niniejszej pracy i spostrzeżenia, że społeczne działanie wyprzedza myślenie. Stabilizacja natury oraz destabilizacja społeczeństwa są ze sobą symetrycznie powiązane. Jednakże zależność ta nie jest widoczna dla szeroko rozumianych nauk społecznych, z których wpierw wyprowadza się podsystemy określonych porządków wiedzy (np.: antropologii filozoficznej, ekonomii, polityki czy jak w przypadku Rousseau - etnologii), te zaś swoją jedność czerpią dopiero z abstrakcyjnej pracy rozumu. Świat pozostaje w ten sposób uporządkowany, lecz tylko z perspektywy epistemologii ${ }^{40}$.

Zamiast dialektyki mamy więc symetrię i wzajemne procesy warunkowania. „Wobec zagrożeń, jakie grupy ludzkie stwarzają dla siebie wzajemnie pisze Norbert Elias - ludzkość [...] pozostaje w pułapce stanu wysokiego uwikłania wiedzy o społeczeństwach, które sterują ich działaniami, potęgując jeszcze te zagrożenia i odwrotnie, stoi w obliczu niebezpieczeństw, potę-

${ }^{39}$ J. Kmita, Prawda zwycięża nie bez oręża, s. 138-146, [w:] tenże, Czarnoksięstwa humanistów, Poznań 2015.

${ }^{40}$ „Zasada symetrii oddaje niezrównane usługi, jeśli chodzi o rozstanie z cięciami epistemologicznymi, apriorycznymi podziałami na nauki uznane i odrzucone albo sztucznymi rozróżnieniami na socjologów badających wiedzę, badających systemy przekonań i badających nauki” (B. Latour, Nigdy nie byliśmy nowocześni, przeł. M. Gdula, Warszawa 2011, s. 135). 
gujących z kolei uwikłanie form ich wiedzy" ${ }^{41}$. Pojęcie symetrii odsłania zatem fakt, że społeczeństwo jest konfrontowane ze sobą samym, zagrożeniem zaś wynikającym z tej konfrontacji nie jest niewiedza, lecz systemy wiedzy naukowej ${ }^{42}$, potęgujące jeszcze bardziej złożoność świata społecznego. Zauważmy, że w ten sposób utrzymywanie postulatu autonomii rozumu sprawia, że coraz bardziej rozrasta się przepaść pomiędzy tym, co dzięki nauce można zdziałać, a tym, co rozum może sobie wyobrazić. Rozum nie posiada ani praktycznych, ani intelektualnych środków, by zapanować nad rzeczywistością, którą wraz z rozwojem nauk aktywnie wytwarza.

Sporo racji mieli więc T. Adorno i M. Horkheimer, definiując Oświecenie jako proces wtórnej mitologizacji ${ }^{43}$, choć nie dostrzegali jednocześnie niedogodności praktycznych, jakie stwarzają w tej sytuacji krytyczne kompetencje rozumu. Rozum krytyczny w ramach dialektyki restytuuje jedynie podstawy własnej zasadności tylko po to, by ponownie je odrzucić:

[Oświecenie] przemawia głosem proroków i religijnych reformatorów, różnych świeckich i świętych mędrców-nauczycieli życia, mistyków, kulturowych dewiantów i osamotnionych poetów. I dopiero w naszym nowożytnym świecie z wolna zaczął odzyskiwać swą ojczystą mowę, którą jest oczywiście jeden i ten sam uniwersalny język europejskiego logosu, czyli słowa rozumnego albo mówiącego rozumu, język dyskursywnej racjonalności pojęć, norm i sensów, który również siłę napędową swej krytycznej samokontestacji czerpie już nie z żadnego transcendentnego »zewnątrz«, lecz wyłącznie ze swej własnej, immanentnej gramatyki, jako że jest ona zarazem jego jedyną logiką, hermeneutyką i etyką ${ }^{44}$.

Dialektyka i krytyka mają więc charakter rekonstrukcyjny. Działają jedynie post factum i w tym sensie ich wychylenie w przyszłość odtwarza jedynie teraźniejszość $\mathrm{w}$ takim sensie, że korzysta ze znanych sobie kompetencji w nowym kontekście. Z pewnością takie podejście nadal jest ważne i cenne $\mathrm{w}$ formułowaniu diagnoz, lecz nie czyni rzeczywistości bardziej zrozumiałą. Wręcz przeciwnie, nieustanny ruch samokontestacji przekształca się w za-

\footnotetext{
${ }^{41}$ N. Elias, Neutralność i zaangażowanie, przeł. J. Stawiński, Warszawa 2003, s. 25.

${ }^{42}$ Patrz: U. Beck, Społeczeństwo ryzyka, przeł. S. Cieśla, Warszawa 2002.

${ }^{43}$ Patrz: T. Adorno, M. Horkheimer, Dialektyka Oświecenia, przeł. M. Łukasiewicz, Warszawa 1994.

${ }^{44}$ M. Siemek, Rozum między świattem i cieniem Oświecenia, s. 286-287, posłowie, [w:] T. Adorno, M. Horkheimer, Dialektyka Oświecenia, przeł. M. Łukasiewicz, Warszawa 1994.
} 
mknięty mechanizm autopojezy ${ }^{45}$, który sprzyja redukcji złożoności świata społecznego, powodując samo-odtwarzanie aktualnie obowiązującego porządku. Złożoność świata społecznego w obrębie systemów wiedzy naukowej ulega więc nieodzownej korelacji w procesach przetwarzania i redukcji, jakie dokonują się w ich obrębie. Stąd też nauki społeczne potrafią sprawnie identyfikować sprzeczności, lecz nie są ich już w stanie kontrolować we wiarygodnej syntezie, dlatego tak naprawdę syntezy dokonują tylko po to, by utrzymać własne kompetencje krytyczne. Pojęcie symetrii z kolei pozwala spojrzeć na rzeczywistość z perspektywy wzajemnie warunkujących się praktyk społecznych, które uwrażliwiają myślenie na problematykę złożoności. Jednakże sama tylko możliwość symetrycznego uchwycenia złożoności jako problemu stanowi poważny problem teoretyczny. Czym innym jest bowiem wykrywanie multiplikujących się sieci współzależności, a czym innym dostrzeganie $\mathrm{w}$ ich obrębie mechanizmów ontologicznej stabilizacji, a tym samym nabywania kompetencji ich przekształcania. Symetria bez momentów autonomizacji i pracy abstrakcyjnych pojęć staje się jałowym wysiłkiem, ulubionym zajęciem dla postmodernistów. Nie chodzi tu więc o wykluczenie dialektyki oraz krytyki na rzecz symetrii, lecz sojusz mający z jednej strony zachować emancypacyjny etos Oświecenia, czyli umiejętność dokonywania odważnych syntez (nie tylko na potrzeby krytyki), z drugiej zaś uniknąć jego epistemologicznych pułapek.

\section{Zakończenie: w obronie rozumu nie do końca oświeconego}

Wiara w rozum zdolny kształtować świat społeczny bez wątpienia uległa dziś wyczerpaniu, a skutki tego wyczerpania nawet dla entuzjastów myśli Oświecenia są rozczarowujące. Jeśli bowiem Oświecenie w obiegowym rozumieniu tego terminu miało oznaczać pełną racjonalizację, w sensie podważenia hegemonii obyczaju, wyrugowania zabobonu w myśleniu o świecie społecznym, stworzenia obiektywnych oraz rozumnych struktur ekono-

45 „Auto-referencja [autopojeza] jest korelatem presji złożoności świata - pisze Niklas Luhmann. Nigdzie w świecie złożoność świata nie może być adekwatnie odwzorowana, opracowana i kontrolowana, ponieważ w odpowiednim stopniu podwyższałoby to tę złożoność. Zamiast tego kształtuje się auto-referencja, która może być respektowana na potrzeby przetwarzania złożoności” (N. Luhmann, Systemy społeczne, przeł. M. Karczmarczyk, Kraków 2007, s. 413). 
miczno-prawnych wolnych od pozaracjonalnych sankcji, zwiększających udział jednostek w kształtowaniu ich własnego losu, to dziś myśliciele i badacze zajmujący się problematyką społeczną mogą nazwać siebie oświeconymi, o tyle tylko, o ile pozostają krytyczni wobec tak rozumianego projektu.

Współczesny świat jest zbyt złożony, by objąć go rozumem, ale nie aż na tyle złożony, by nie poddawać go całkowitej krytyce. Ta sprzeczność pokazuje, jak głęboko tkwi we współczesnych systemach wiedzy naukowej dziedzictwo rozumu oświeconego. Myśliciele wszelkiej maści bardzo szybko przywykli do traktowania współczesnego świata $\mathrm{w}$ taki sposób, w jaki Oświecenie traktowało swoją własną przeszłość, czyli jako źródło cierpień, z tą tylko różnicą, że dziś nikt nie potrafi sformułować propozycji przezwyciężenia takiego stanu rzeczy. Krytyka to być może jedyne dziedzictwo Oświecenia, do którego można się dziś bez wstydu przyznać. Z kolei jej „prometejski”"46 wymiar, upatrujący w naukach obietnicę lepszego świata, zostaje całkowicie odrzucony. Zupełnie tak, jakby to rzeczywistość wyprzedzała myślenie i dyktowała warunki, samo myślenie zaś potrafiło już tylko ustosunkowywać się do tego, co rzeczywiste, na poziomie krytyki. Owo myślenie przypomina Heglowską postać świadomości nieszczęśliwej, całkowicie pozbawioną wpływu na bieg świata, której pozostaje jedynie postawa moralnego oburzenia.

Nasi współcześni - powiada Zygmunt Bauman - przekonali się już, i to wielokrotnie, na własnej skórze, że gorliwie wyczekiwana przyszłość z chwilą, gdy się przeradza w teraźniejszość, obdarza nas drobną tylko cząstką tego, czego żeśmy się radośnie spodziewali - a za to obficie raczy nas nowymi, przedtem nam nieznanymi bolączkami i troskami... O ileż bardziej łatwe do zniesienia jawią się nam dalekie od doskonałości, ale przytulne, bo znane doznania przeszłości niż strach budzące, bo nieznane i nieprzewidywalne odkrycia i wynalazki przyszłości! ${ }^{47}$

Tak naprawdę jednak to nie przyszłość budzi strach, lecz teraźniejszość. Oświecenie nauczyło nas bowiem postrzegać przyszłość jako potencjalność ukrytą w teraźniejszości, która, jak powiadał wcześniej już przywołany J. J. Rousseau, nie może stanowić uzasadnienia dla przyszłego stanu rzeczy, gdyż to oznaczałoby jedynie reprodukcję wyzysku i nędzy. W tym sensie poprzestawanie na oświeconej krytyce ujmuje przeszłość jedynie jako drogę do

\footnotetext{
${ }^{46}$ Patrz: A. W. Nowak, Wyobraźnia ontologiczna, Warszawa 2016.

${ }^{47}$ Wywiad z Zygmuntem Baumanem w „Krytyce Politycznej”: http://krytykapolityczna.pl/ swiat/bauman-goldkorn-wywiad/ (dostęp on-line: 18.01.2017).
} 
aktualizowania teraźniejszości, nad którą nie można zapanować, ani której nie można już przezwyciężyć. Nasz stosunek do przyszłości zależy więc od tego, jak rozumiemy teraźniejszość.

W rzeczywistości dyspozycje trwale wpojone przez możliwości i niemożliwości, ułatwienia i zakazy wpisane w warunki obiektywne (a dzięki systematycznym regularnościom wpisane przez naukę jako obiektywne...), wyzwalają dyspozycje obiektywnie przystające do tychże warunków i w pewnym sensie uprzednio już przystosowane do stawianych przez nie warunków. Z tego względu okazuje się, że najmniej prawdopodobne praktyki zostają wykluczone przed jakimkolwiek zbadaniem z tej racji, że są nie do pomyślenia, w wyniku swoistego bezpośredniego podporządkowania się ładowi, który z konieczności czyni cnotę, czyli odrzuca to, co odrzucone i chce tego, co nieuniknione ${ }^{48}$.

Stąd też prawdziwymi marzycielami są właśnie ci ludzie, którzy stanowczo odrzucają etos Oświecenia, czyli wiarę w możliwość budowy lepszego i bardziej sprawiedliwego świata. Jak zauważa Andrzej W. Nowak: „Postawa krytyczna bez propozycji pozytywnej zmiany to nie nowoczesna myśl emancypacyjna, ale ponowoczesny cynizm"49. To prawda, powrót do projektu Oświecenia, naiwnej wiary $\mathrm{w}$ to, że dzięki omnipotencji rozumu można kształtować życie społeczne i zapanować nad własnym losem, jest już niemożliwy. Nie jest to jednak powód do tego, by poprzestawać tylko na pracy krytycznej i nie szukać nowych rozwiązań. Oświecenie nie musi wcale oznaczać totalnej porażki i labiryntu bez wyjścia, lecz lekcję do odrobienia.

\section{Bibliografia}

Adorno T., Horkheimer M., Dialektyka Oświecenia, przeł. M. Łukasiewicz, Warszawa 1994.

Berlin I., Pokrzywione drzewo człowieczeństwa, przeł. H. Hardy, Warszawa 2004.

Baczko B., J. J. Rousseau, Samotność i wspólnota, Warszawa 1964.

Beck U., Społeczeństwo ryzyka, przeł. S. Cieśla, Warszawa 2002.

Bourdieu P., Medytacje pascaliańskie, przeł. K. Wakar, Warszawa 2006.

Bourdieu P., Zmysł praktyczny, przeł. M. Falski, Kraków 2008.

${ }^{48}$ P. Bourdieu, Zmysł praktyczny, przeł. M. Falski, Kraków 2008, s. 74.

${ }^{49}$ A. W. Nowak, Wyobraźnia ontologiczna, Warszawa 2016, s. 102. 
Buck-Morss S., Hegel, Haiti i historia uniwersalna, przeł. K. Bojarska, Warszawa 2014. Condorcet N., Szkice obrazu postępu ducha ludzkiego przez dzieje, przeł. B. Suchodolski, Warszawa 1957.

Desrosieres A., Politics of large numbers, transl. C. Naish, Harvard University Press, London 1998.

Durkheim E., O podziale pracy społecznej, przeł. K. Wakar, Warszawa 1999.

Elias N., Neutralność i zaangażowanie, przeł. J. Stawiński, Warszawa 2003.

Foucault M., Bezpieczeństwo, terytorium i populacja, przeł. M. Herrer, Warszawa 2010.

Foucault M., Historia seksualności, przeł. T. Komendant, Gdańsk 2010.

Habermas J., Strukturalne przemiany sfery publicznej, przeł. W. Lipnik, M. Łukasiewicz, Warszawa 2006.

Hegel G. W. F., Wykłady z historii filozofii, przeł. Ś. F. Nowicki, t. I i II, Warszawa 1994.

Hegel G. W. F., Fenomenologia ducha, przeł. Ś. F. Nowicki, Warszawa 2010.

Holbach P., System przyrody, przeł. J. Jabłońska, H. Suwała, t. I i II, Warszawa 1977.

Kmita J., Czarnoksięstwa humanistów, Poznań 2015.

Koselleck R., Warstwy czasu, przeł. K. Krzemieniowa, J. Merecki, Warszawa 2012.

Koselleck R., Semantyka historyczna, przeł. W. Kunicki, Poznań 2012.

Koselleck R., Krytyka i kryzys, przeł. J. Duraj, M. Moskalewicz, Warszawa 2015.

Latour B., Polityka natury, przeł. A. Czarnacka, Warszawa 2009.

Latour B., Nigdy nie byliśmy nowocześni, przeł. M. Gdula, Warszawa 2011.

Luhmann N., Systemy społeczne, przeł. M. Karczmarczyk, Kraków 2007.

Marquard O., Rozstanie z filozofia pierwszych zasad, Warszawa 1994.

Marquard O., Apologia przypadkowości, przeł. K. Krzemieniowa, Warszawa 1994.

Marks K., Engels F., Manifest komunistyczny, przekł. zbiorowy, Warszawa 1949.

Nietzsche F., Wiedza radosna, przeł. L. Staff, Kraków 2004.

Nowak A., Wyobraźnia ontologiczna, Warszawa 2016.

Ossowski S., Demokracja w świecie napięć politycznych, Warszawa 1951.

Rousseau J. J., Trzy rozprawy z filozofii społecznej, przeł. H. Elzenberg, Warszawa 1956.

Rousseau J. J., Emil, czyli o wychowaniu, przeł. W. Husarski, t. I i II, Wrocław 1955.

Rousseau J. J., Umowa społeczna, przeł. A. Peretikowicz, Kęty 2007.

Sloterdijk P., Kryształowy pałac, przeł. B. Cymbrowski, Warszawa 2011.

Sorel G., Złudzenia postępu, przeł. E. Breiter, Kraków 2015.

Starobinski J., Emblematy rozumu, przeł. M. Ochab, Warszawa 1997.

Bauman Z., wywiad: http://krytykapolityczna.pl/swiat/bauman-goldkorn-wywiad (dostęp: 18.01.2017).

Hume D., O stanie średnim: http://www.nowakrytyka.pl/spip.php?article463 (dostęp: 31.03.2017). 


\section{Abstract \\ Defence of Not Strictly Enlighted Reason. Several Remarks About Reflexivity and Critic}

The paper presents process of autonomisation of enlightened reason and its influences on the constitution of social sciences. My thesis is that the gap between dynamic ongoing social complexity and social science has been increasing since Enlightenment. Moreover, I argue that the mode of conceptualization of social world by social sciences multiplies complexity rather than explains it. To show this dependency I use the well-known example of a deficit of food in eighteenth-century France. Despite these problems I claim that enlightened reason is still indispensable in scientific practice.

Key words: Enlightenment, social science, nature, autonomy, reflexivity, complexity, reason 